REVIEW

This paper is dedicated to the $70^{\text {th }}$ anniversary of the founding of Physiologia Bohemoslovaca (currently Physiological Research)

\title{
Pancreatic Stellate Cells - Rising Stars in Pancreatic Pathologies
}

\author{
Pavel HRABÁK ${ }^{1}$, Marta KALOUSOVÁ ${ }^{2}$, Tomáš KRECHLER ${ }^{1}$, Tomáš ZIMA ${ }^{2}$ \\ ${ }^{1} 4^{\text {th }}$ Department of Medicine - Department of Gastroenterology and Hepatology, First Faculty of \\ Medicine, Charles University and General University Hospital in Prague, Czech Republic, ${ }^{2}$ Institute \\ of Medical Biochemistry and Laboratory Diagnostics, First Faculty of Medicine, Charles University \\ and General University Hospital in Prague, Czech Republic
}

Received September 29, 2021

Accepted November 2, 2021

\begin{abstract}
Summary
Pluripotent pancreatic stellate cells (PSCs) receive growing interest in past decades. Two types of PSCs are recognized vitamin A accumulating quiescent PSCs and activated PSCs- the main producents of extracellular matrix in pancreatic tissue. PSCs plays important role in pathogenesis of pancreatic fibrosis in pancreatic cancer and chronic pancreatitis. PSCs are intensively studied as potential therapeutical target because of their important role in developing desmoplastic stroma in pancreatic cancer. There also exists evidence that PSC are involved in other pathologies like type- 2 diabetes mellitus. This article brings brief characteristics of PSCs and recent advances in research of these cells.
\end{abstract}

\section{Key words}

Pancreatic stellate cells • Pancreatic cancer • Diabetes mellitus • Chronic pancreatitis • Tumor microenvironment

\section{Corresponding author}

Marta Kalousová, Institute of Medical Biochemistry and Laboratory Diagnostics, First Faculty of Medicine, Charles University and General University Hospital in Prague, Kateřinská 32, 12108 Prague 2, Czech Republic. E-mail: marta.kalousova@lf1.cuni.cz

\section{Introduction}

Stellate cells in humans were for the first time described by the great German pathologist von Kupffer in 1876. Kupffer described black stained "Sternzellen" in his letter to a famous German anatomist Wilhelm
Waldeyer as the star-shaped cells localized in perisinusoidal spaces in the liver tissue revealed by gold chloride method. At that time, von Kupffer (1876) (who formerly described resident macrophages in liver (recently known as Kupffer cells) was uncertain about the role of hepatic stellate cells and considered them to be liver macrophages. After several decades Ito et al. (1952) proved vitamin A storing ability of these perisinusoidally localised cells and later Wake et al. (1999) described differences between Ito's stellate cells and Kupffer cells in the liver. These findings were followed by increased interest in hepatic stellate cell's (HSC's) functions and further characterisation of these cells. Nowadays it is clarified that HSC have a crucial role e.g., in liver regeneration, tissue repair, production of extracellular matrix and immunomodulation.

Surprisingly, not the same attention was aimed at pancreatic stellate stells (PSCs). Unlike other pancreatic cells e.g. pancreatic islet cells, acinar or ductal cells, existence of PSCs was unrecognized until 1982 (106 years after Kupffer's discovery of HSC), when Watari et al. (1982) found vitamin A accumulating cells in pancreatic tissue. In 1998 PSCs were successfully isolated from rat and human pancreas, which enabled further research of PSCs physiology in vitro. Apte et al. (1998) developed a technique for isolation of PSC based on lower density of PSCs caused by high amount of lipid vacuoles. It is supposed that it is possible to use density gradient based centrifugation of pancreatic cells suspension to isolate PSC. Since that time PSC received growing interest of researchers focused on pancreas and 
their research enabled deeper insight into PSCs role in pancreatic (patho)physiology. In this brief review, we would like to introduce recent knowledge about the relationship between PSCs and distinct pancreatic pathologies.

\section{Biology of PSC}

\section{Origin of PSCs}

Pancreatic stellate cells comprise about $7 \%$ of pancreatic cells and are found both in exocrine and exocrine parts of the pancreatic tissue. The origin of PSCs remains unclear. Despite the expression of neuroendocrine tissue specific markers, PSCs are supposed to be of mesenchymal origin as demonstrated by Asahina et al. (2009).

Existing evidence suggests that PSCs originate from mesenchymal cells, bone marrow cells (Sparmann et al. 2010) and certain type $\left(\mathrm{CCR}^{2+}\right)$ of monocytes (Ino et al. 2014).

\section{Characteristics of PSCs}

PSCs surround small pancreatic ducts and blood vessels and are mostly present in the basolateral part of pancreatic acinar cells. They can be identified by using immunohistochemical analysis because PSCs present some specific markers such as vimentin, desmin, glial fibrillary acidic protein (GFAP), neural growth factor (NGF), neural cell adhesion molecule (NCAM), synemin and nestin (Apte et al. 1998).

Presence of various intracellular filaments shows a broad spectrum of possible functions of PSCs (Uyama et al. 2006, Omary et al. 2004).

PSCs typically exhibit blue-green fluorescence based on vitamin-A accumulation in intracellular lipid vacuoles when exposed to $328 \mathrm{~nm}$ UV light (Watari et al. 1999).

Features of PSC varies depending on their location and state. Recent systematic work of Zha et al. (2014) revealed that PSC are present in pancreatic islets as well. These cells are characterized by lower concentration of vit. A containing droplets and are rapidly activated in comparison to parenchymal PSC. After activation, islet-localized- PSCs produce lower amount of activation specific protein SMA-alfa compared to PSC in pancreatic parenchyma. After activation, islet PSCs exhibit lower proliferative and migrative potential. Recently, several works were published, where the authors propose islet PSCs as possible stem cells of beta cells of Langerhans's islets (Zhou et al. 2019, Zha et al. 2014).

\section{PSCs and vitamin A}

The ability of PSCs to store retionoids seems to be important for pancreatic tissue homeostasis as retinoids are vital for differentiantion of pancreatic duct cells and regulating cells death in pancreatic tissue. (Tulachan et al. 2003)

The presence of vitamin A molecules - retinoids containing lipid droplets seems to be the main characteristic of quiescent PSC. The PSCs are the only vitamin-A storing cells in pancreatic tissue, but play just a minor role in retinoid storing system of the human organism, as quitescent hepatic stellate cells contain $50-80 \%$ of total body vitamin A. (Blaner et al. 2009) Retionoids, especially ATRA (all trans-retinoic acid) are involved in regulation of gene trascription, where ATRA controls expression of hundreds of genes (Balmer et al. 2002). Mechanism of their accumulation in quitescent phase and loss during activation of PSCs remains unclear, but it seems that retinoids stored in lipid rich droplets are important for maintaining quiescent phase of PSCs e.g. by their possible interaction with peroxisome proliferatoractivated receptor beta/delta $(\operatorname{PPAR} \beta / \delta)$ (Berry et al. 2009).

Bleul et al. reported markedly reduced levels of all-trans-retinoic acid and all-trans-retinol in PDAC tissue obtained from human and mouse pancreata. This suggests, together with work of Colvin, the importance of retinoid signalling in PDAC pathophysiology (Bleul et al. 2015, Colvin et al. 2011).

The relationship of vitamin A and pancreas was recently reviewed in detail by Zhou et al. (2021).

\section{Phenotypes of PSCs: Activated vs. quiescent PSCs}

\section{Quiescent PSCs}

There exist basically two phenotypes of PSC based on the presence of various features (Table 1). Relatively little is known about quiescent PSCs (qPSCs). In healthy pancreas, qPSCs contain abundant vitamin A containing lipid droplets, characteristically express desmin, glial fibrillary acidic protein (GFAP) - which is specific for pancreatic stellate cells (Ding et al. 2008), nestin and vimentin. These quiescent PSC are "resting" cells. Their ability to proliferate, migrate or produce 
Table 1. Main differences between quiescent and activated PSCs

Quiescent PSCs

Rich in vitamin A droplets

Alpha SMA negativity

Low ability to proliferate and migrate

Balanced ECM turnover (low MMP, higher TIMPs)
Activated PSCs

Loss of vitamin A containing droplets

Alpha SMA positivity

High migration and proliferation activity

High ECM production (high MMP, low TIMPs)

Abbreviations: PSCs - pancreatic stellate cells; SMA - smooth muscle actin; ECM - extracellular matrix; MMP - matrix metalloproteinases, TIMP - tissue inhibitor of metalloproteinases. Modified from: Wu Y et al. (2021) and Jin G et al. (2020).

extracellular matrix is rather limited compared to activated PSC.

qPSCs create a network adjacent to capillary and ductal structures of pancreas, but are present in pancreatic islets as well (Zha et al. 2014). In quiescent state PSCs produce limited amount of MMP and TIMPs to maintain homeostasis of the extracellular matrix (Phillips et al. 2003).

\section{Activated PSCs}

After activation the appearence of PSCs changes dramaticaly into myofibrobalst like phenotype. Activated PSCs express various proteins such desmin and $\alpha$-SMA (which differentiates them from fibroblasts), collagen I and III, various metaloproteinasas and their inhibitors, fibronectin, ICAM - 1 (Masamune et al. 2002), cadherine 11 (Row et al. 2016) and lose vitamin A containting lipid droplets.

Activated spindle-shaped PSCs exhibit several functions which are involved in pancreatic tissue repair. This is done mainly by production of ECM, which replaces destroyed parenchymal cells. This process is under normal circumstances limited to damaged area. Under patological circumstances e.g. chronic pancreatitis or pancreatic cancer this process continues and results in pancreatic fibrosis with loss of endocrine and exocrine pancreatic function. Activated PSCs also produce a variety of cytokines, which further serve as an autoactivators of PSC.

There exists evidence of the role of activated PSCs in phagocytosis in inflammed areas of pancreas (Shimizu et al. 2005).

\section{Molecular mechanism of PSCs activation}

Activation of PCSs seems to be one of the key points of generating pathological microenvironment leading to progression of such deteriorating conditions as chronic pancreatitis and pancreatic cancer. This microenvironment, characterized by excessive production of fibrous extracellular matrix, is responsible for chemoresistance of PDAC, promotes tumor growth and metastasing. The activation can be provided by both autocrine and paracrine mechanisms. There exist several mechanisms of extracellular signalling involved in activation of PSCs, such as cytokines, non-coding RNAs, oxidative stress, hyperglycemia and ion channels signalling (Jin et al. 2020).

\section{PSCs activation and cytokines}

Most of the cytokines are produced by activated PSCs as well, which fact ephasises the crucial role of vicious circle of PSCs autoactivation while once stimulated. This process is a possible mechanism of fibrogenesis in certain pancreatic pathologies - mainly chronic pancreatitis.

Transforming growth factor beta 1 (TGF- $\beta 1$ ) is a strong fibrosis inducing agent in pancreatic tissue. It activates MAPK pathway (Xu et al. 2018), which leads to change of PSCs phenotype by increased mRNA expression of extracellular signal-regulated kinases (ERK) and C-Jun amino terminal kinase (JNK) (Fitzner et al. 2004). It has been proved that PSCs produce TGF- $\beta 1$, which suggests, that this "auto-activation" by TGF- $\beta 1$ followed by increased production of ECM by PSCs is one of the possible mechanisms of excessive fibrosis in chronic pancreatitis. This production of TGF- $\beta 1$ by PSC can be hampered by ATRA. ATRA prevent PCSs to mechanically release TGF- $\beta 1$ via downregulation of organizing of inactive complex with latent TGF- $\beta$ binding protein and thus liberating TGF- $\beta 1$. (Sarper et al. 2016). TGF- $\beta 1$ induced hydrogen peroxideinducible clone-5 (Hic-5) deficiency inhibits activation of PSCs in CP model as well as iSMAD interferes with TGF- $\beta$ signalling pathway, which emphasises the role of TGF- $\beta$ /SMAD pathway in PSCs activation 
(Lin et al. 2021).

Recent findings emphasise the role of interplay between various cytokines - mainly PDGF, TGF- $\beta 1$ and Yes-associated protein 1 (YAP). YAP modulates cell proliferation and development as well as apoptosis in various tissues. YAP is also involved in cancer cell growth. Besides other pathways, YAP interacts with SMAD pathway, and plays a role in sustaining of activated state of PSCs, partialy by interacting with PDGF. (Hu et al. 2019)

The main source of PDGF in pancreatic tissue are macrophages and cancer cells. While activated, PCSs are another important source of PDGF. PDGF was shown to be a potent mitogen and co-cultivation of PSC and PDGF led to increased production of ECM by those cells. (Luttenberger et al. 2000) PDGF is also overexpressed in chronic pancreatitis (Ebert et al. 1998).

Another source of PDGF and TGF- $\beta 1$ in pancreas could be platelets. In pancreatitis event, as demostrated by Gress et al. (1994), platelets accumulating in inflammed areas of pancreatic tissue are source of PDGF, which further stimulates fibrogenesis by activatating PSC (Luttenberger et al. 2000).

\section{PSCs activation and hypoxia}

Hypoxia is another factor leading to PSCs activation (Estaras et al. 2020). Increased fibrogenesis by PSCs is often accompanied by hypoxemic environment, which results in increased proliferation of PSC. Hypoxiainducible factor-1 (which level rises in hypoxic condition e.g. in cancer stroma) influences the fibrogenesis by PSCs via upregulating hepatoma-derived growth factor (HDGF) (Ide et al. 2006).

Besides impairment of pancreatic exocrine function, hypoxia mediated activation of PCSs leads to death of beta cells of pancreatic islets (Kim et al. 2020).

Inflammation of pancreatic tissue accompanied by oedema of adjacent structures as well as obstruction of pancreatic duct are conditions which increase pressure in pancreatic parenchyma. A study of Asaumi et al. (2007) showed that externally applied pressure increase reactive oxygen species (ROS) synthesis as well as synthesis of ECM by PSCs. This finding supports routine praxis of reducing of intraductal pressure in pancreatic parenchyma by drainage, stone removal, or surgery.

\section{PSCs activation and miRNA}

ncRNA accounts for about $70 \%$ of human genetic information and as such is involved in many biological processes. (Storz G 2002). ncRNA is usually divided into following groups: small interfering RNA, microRNA and long ncRNA.

MicroRNAs (miRNA) are relatively small RNA molecules which have important role in regulating many cell functions - like differentiation, proliferation, or carcinogenesis.

There have been described various changes of miRNA profile in conditions such as PDAC and chronic pancreatitis (Chhatriya et al. 2019, Xin et al. 2017). miRNA can have both inhibitory and promoting function on PSCs.

PSCs's miRNA has different profile before and after activation of PSCs This study revealed that some of more expressed miRNAs interact with signalling pathways, cellular development and cell activation, e.g. upregulated miR-31 (Masamune et al. 2014).

Histone deacetylase inhibitors reduce acetylation in histones, which is followed by increased expression of miR-15 and miR-16 which further leads to repression of TGF- $\beta 1 /$ SMAD pathway. This results in reduction of fibrogenesis by PSCs and increased apoptosis of PSCs in chronic pancreatitis (Ji et al. 2020).

Other structures involved in activation of PSCs are exosomes - the carriers of miRNA. Exosomal miR-130a-3p participates on PSCs activation by affecting the cellular peroxisome proliferator-activated receptor gamma PPAR- $\gamma$ (Wang et al. 2021).

MiRNA is also important in PCSs and tumor cells crosstalk: Recent study revealed that hypoxiainduced activated PSCs are source of exosomes which via phosphatase and tensin homolog (PTEN) activate protein kinase B pathway in PDAC cells which increase proliferation and invasion of these cells (Cao et al. 2021). The role of PSCs derived exosomes in PDAC cells proliferation was observed in several studies (Masamune et al. 2017).

Long ncRNA has length about 200 to $100,000 \mathrm{bp}$. These molecules involved in regulating of gene expressions were studied in connection with pancreatic cancer (Zhou et al. 2020), but little is known about their role in pancreatic fibrosis. Wang et al shows that certain lncRNAs e.g., STX12 lncRNA involves through miR-130b and miR-148a target mRNAs (SMAD5 and IL6ST) and have promoting effect of PSCs activation (Wang et al. 2016). On the contrary expression of miRNA 200a inhibits PSCs activation (Xu et al. 2017).

MiRNA let-7d through inhibiting expression of 
thrombospondin 1 reduces activation of PSCs and reduced miRNA let-7 $\mathrm{d}$ is a potential serum biomarker of PDAC (Suzuki et al. 2017).

\section{PSCs activation and oxidative stress}

Oxidative stress leading to production of ROS (e.g., nitric oxide) is associated with pancreatitis. There exists a well described link between calcium mediated activation of pancreatic enzymes and oxidative stress which is one of the mechanisms of acute pancreatitis onset (Petersen et al. 2006).

There has been proved (in rat PSCs) activity of nitric oxide synthase-2 (NOS2) following exposition of PSCs to pathogen associated molecular pattern (PAMP) (Jakubowska et al. 2016).

Coenzyme Q10 as potent antioxidant ameliorates pancreatic fibrosis and activation of PSCs via PI3K/AKT/mTOR signalling pathway (Xue et al. 2019).

\section{Activation of PSCs and alcohol and smoking}

Alcohol-induced chronic pancreatitis is a burden for healthcare system in last decades and as a chronic inflammatory condition bears an increased risk of PDAC development. Alcohol activates PSCs by several mechanisms mainly due to its metabolism to acetaldehyde (PSCs exhibit alcoholdehydrogenase) and generating oxidative stress by inducing inflammatory changes in pancreas. (Apte et al. 2000) Endotoxin lipopolysaccharide has been recognised as a trigger of alcoholic chronic pancreatitis. TGF betal -SMAD 2,3 pathway is the main axis of activation of PSCs in alcoholic chronic pancreatitis (Sun et al. 2018). There were observed increased levels of IL-6 in alcoholinduced-chronic pancreatitis (Pedersen et al. 2004). IL-6 promotes TGF -betal secretion by PSCs and via ERK pathway directly activates PSCs (Aoki et al. 2006).

MAPK kinase pathway is activated during exposure of PSCs to ethanol and acetaldehyde (McCarroll et al. 2003).

The relationship between PSC and alcohol intake seems to be even more complex, since alcohol increases gut permeability which can lead to release of endotoxins and lipopolysaccharides which activates PCSs probably via Toll-like receptor 4 (TLR-4) and CD-14 (Vomlaufen et al. 2007).

There seems to be links between environmental factors as alcohol and high caloric intake resulting in obesity which have impact on PSCs metabolism and thus increasing risk of pancreatic cancer. Obesity associated type 2 diabetes mellitus is associated with increased levels of lipopolysaccharides and TNF alpha (adipose tissue derived) which have effect on PSCs activation (Pandol et al. 2012).

Calcium signalling is a universal mechanism of regulating many biological processes. In pancreatic tissue, calcium signalling pathways contribute to regulation of secretion of pancreatic enzymes. Besides acinar cells, $\mathrm{Ca}^{2+}$ signalling is an important signalling pathway in PSCs.

Unlike pancreatic acinar cells, PSCs do not respond to acetylcholine or cholecystokinin stimuli by $\mathrm{Ca}^{2+}$ increase in cystosole. On the contrary bradykinin elicits Ca signals from PSCs (Gryschenko et al. 2016).

As a consequence of alcohol-induced pancreatic injury inflammatory mediators e.g., kallikrein, are released, which increases levels of bradykinin. Bradykinin is involved in $\mathrm{Ca}^{2+}$ signalling playing an important role in activation of PSCs as PSCs express bradykinin receptor type 2 (Apte et al. 2003).

Ion channels in general seem to be crucial in PCSs metabolism regulation. One study revealed that inhibition of $\mathrm{KCa} 3.1$ is followed by reduced migration and chemotaxis of PSCs (Storck et al. 2017).

Smoking is another important environmental factor contributing to PSC activation via nicotinic acetylcholine receptors (nAChRs), which are expressed by PSCs (Lee et al. 2015) and by upregulation of IL-22 (Li et al. 2020).

\section{PSCs in pancreatic pathologies}

\section{PSC and DM2}

It is widely recognized, that DM2 is a risk factor of pancreatic cancer (De Souza et al. 2016). PSCs respond to glucose levels as they express glucose transporters GLUT 1-3 (Kiss et al. 2015).

DM 2 is a condition accompanied by chronic hyperglycemia, which leads to activation and proliferation of PSCs (Hong et al. 2007).

The relationship between PSCs and type 2 diabetes mellitus seems to be bilateral. Firstly, in diabetes, hyperglycemia can induce PSCs activation via renin-angiotensin system (RAS) system, promoting fibrosis in pancreatic islets (Ko et al. 2006). Hyperglycemia stimulates via RAS TGF beta synthesis which is one of key mediators of PSCs activation. Moreover, in pancreatic islets unlike in rest of pancreatic tissue, PCSs are in case of DM 2 exposed to high levels 
of glucose and insulin. Combination of these two factors, initializing through ERK1/2 phosphorylation activation and proliferation of PSCs can cause islet specific fibrosis, which was observed on mouse models. Especially involvement of RAS system can be a promising therapeutic target in DM 2 therapy (Yang et al. 2020).

Chronic hyperglycemia leads to differentiation into myofibroblast-like phenotype of PSCs via p38 pathway. In chronic hyperglycemic condition PSCs produce more mRNA CXCL12, which can have influence on PDAC cells proliferation (Kiss et al. 2015). GLP-1 - an enzyme involved in glucose homeostasis possibly involves activation of PSC (Yand Y et al. 2013).

Hypoxia can occur within pancreatic islets probably due to high oxygen consumption by insulin producing beta cells. (Sato et al. 2011). Hypoxia in pancreatic islets can activate PSCs resulting in islet fibrosis and further damage of beta cells (Kim et al. 2008).

Interestingly, vitamin A deficiency leads to activation of PSCs and islet fibrosis which is followed by dysfunction of pancreatic islet. This can be reversed by vitamin A supplementation (Zhou et al. 2020). The relationship between PSCs and DM2 is summarized in Fig. 1.

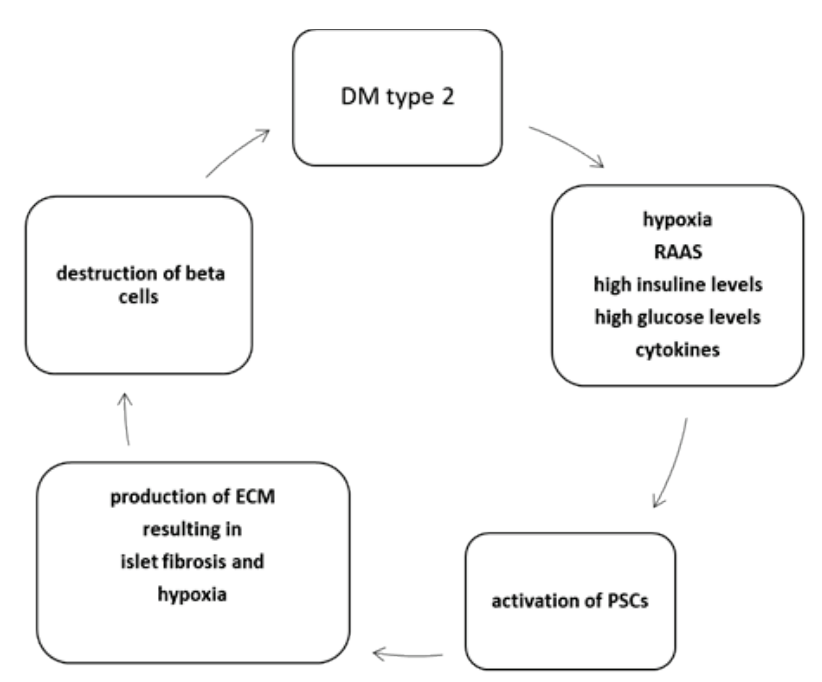

Fig. 1. Relationship between DM2 and PSCs. DM2 is a condition accompanied by environment rich in insulin and glucose within the pancreatic islets. High oxygen consumption by insulin producing beta cells results in hypoxia and oxidative stress. This, in combination with activation of angiotensin II pathway, leads to activation of PSCs. PSCs produce ECM and cytokines which results both directly and indirectly due to islet fibrosis in beta cells destruction. DM type 2 - Type 2 diabetes mellitus, PSCs pancreatic stellate cells; RAAS - renin- angiotensin- aldosterone system; ECM - extracellular matrix. Modified from Kim et al. (2008).

\section{$P S C$ and $P D A C$}

Pancreatic stellate cells comprise about $5 \%$ of normal pancreas but they form about $50 \%$ of desmoplastic stroma of PDAC, which comprise about $90 \%$ of tumor mass (Farran et al. 2019). PDAC is characteristic by massive desmoplastic reaction, where multiple cells, including stellate cells, are involved. Research in last few decades shows emerging role of PSCs in modulation of PDAC microenvironment. Understanding PDAC cells and PSCs crosstalk is important for searching for therapeutical target of pancreatic cancer.

Interactions between tumor cells and PSCs were studied both in vivo and in vitro. Activated PSCs involve many processes within tumor stroma e.g., angiogenesis, ECM production, tumor growth, invasion, and proliferation as well as drug resistance. PSCs potentiate migration, proliferation, and differentiation of PDAC cells, and vice versa PDAC cells promote activation of PSC and their migration and proliferation as well as production of ECM.

PDAC cells influence production of ECM, activation and proliferation of PSCs. Both PDAC cells and PSCs produce cocktail of various cytokines, which stimulate activity and proliferation of both cell lines. Activation of PSCs is stimulated by cytokines like IL-1, IL-6, colony-stimulating factor 1 (CSF1), platelet-derived growth factor BB (PDGF-BB), TGF- $\beta 1$, fibroblastgrowth factor (FGF) (Carter et al. 2021). FGF, located in several tissues, is part of signalling cascade regulating cell proliferation and differentiation (Kang et al. 2019). FGF-1 and -2 are present in PDAC in higher amount than in healthy pancreas and their levels are possibly linked to oxidative stress accompanying PDAC microenvironment. On the contrary, some studies show positive effect of FGF 1 and 2 to cell adhesion and differentiation in PDAC (El-Hariry et al. 2001).

FGF released by PSCs stimulates production of TGF- $\beta 1$ by PDAC cells, which reversely stimulates further proliferation of PSCs. TGF- $\beta 1$, secreted by PSCs as well, downregulates levels of L1 cell adhesion molecule L1CAM which promotes aggressive stem-like phenotype of PDAC cells (Cave et al. 2020).

Surprisingly, it seems, that the role of TGF- $\beta 1$ is rather conflicting as in early stages of PDAC TGF-beta plays inhibitory role, but in advanced stages of PDAC it is involved in epithelial- mesenchymal transformation of PDAC cells (Morrison et al. 2013).

Besides TGF beta1/SMAD axis, other pathways 
are linked to regulation of PDAC cells invasion e.g., stromal cell-derived factor-1/CXCR4 axis or c-Met/PI3K/Akt signalling pathway (Xu et al. 2020, Gao et al. 2010). Galectin-1 / NF-kB axis promotes PDAC metastasing (Erkan et al. 2009). Interplay between PSCs and PDAC cells is depicted in Fig. 2.

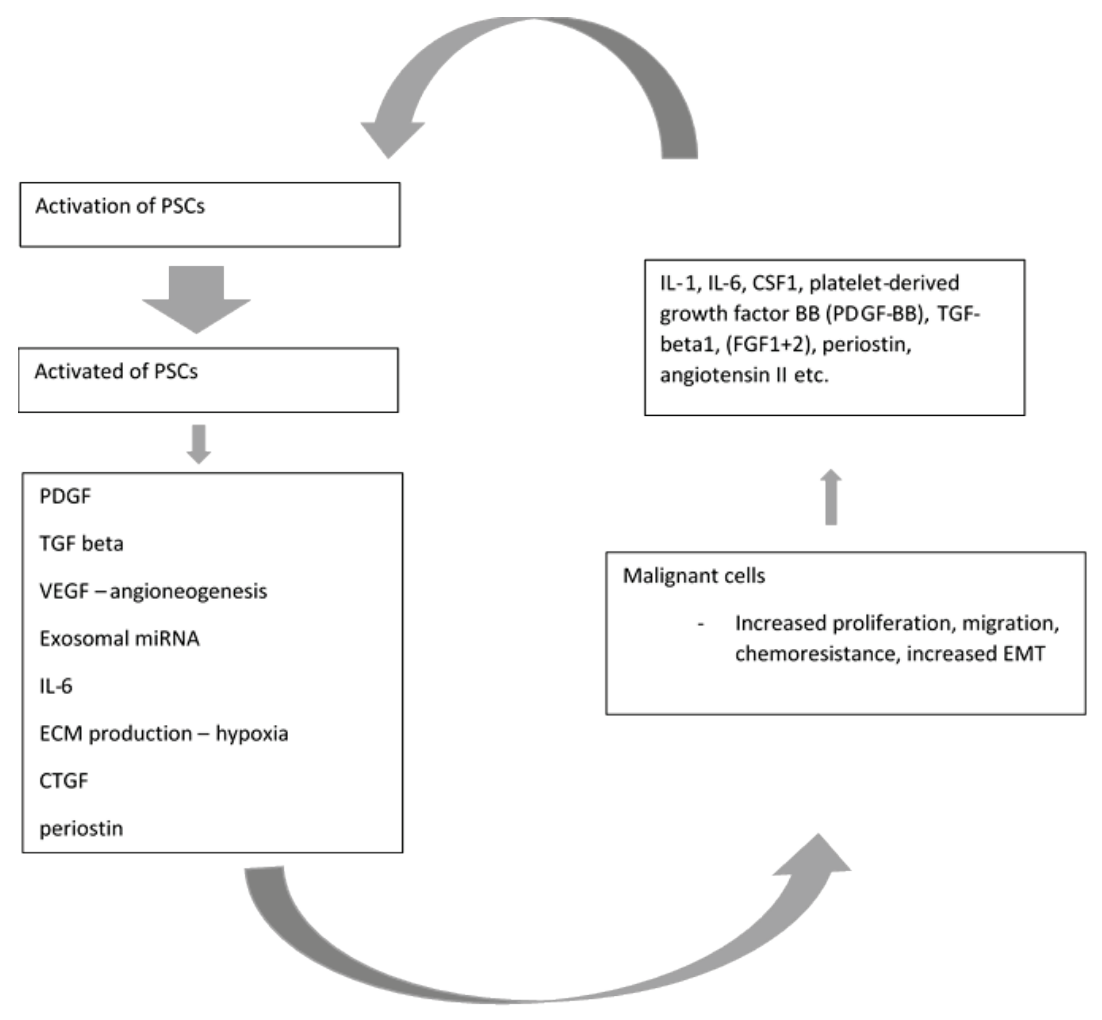

Fig. 2. Paracrine signalling via cytokines produced by malignant cells leads to PCSs activation. While activated, PSCs secrete factors, which increase ability of malignant cells to proliferate and migrate, increase metastatic potential and resistance to chemotherapeutics. Both malignant cells and activated PSCs produce factors which further activate PSCs. PDGF : platelet derived growth factor, VEGF - vascular endotelial growth factor, TGF - tumor growth factor; miRNA microRNA; ECM - extracellular matrix; CTGF connective tissue growth factor; EMT epitelial-mesenchymal transformation; CSF1 colony-stimulating factor 1; FGF - fibroblast growth factor. Modified from: Carter et al. (2021)

MiRNA pathways are also involved in PDAC PSCs crosstalk. Exosomal miRNA is utilized by PDAC cells and contributes to migration and proliferation of PDAC cells. Exosomal PSCs derived miRNA 21 is internalized by PDAC cells and high levels of this miRNA result in increased PDAC cells migration and EMT. (Ma et al. 2020) MiR-4459/KIAA0513 axis involving pancreatic cancer growth and metastasing was described by Shao et al. (2020) Exosomes are also involved in chemoresistance of PDAC treated by gemcitabine (Richards et al. 2017).

In vitro studies shows that co-cultivation of PSCs - and PDAC leads to transition of PDAC cells into fibroblast-like phenotype, reduction of e-cadherin and membrane associated beta catenin expression as well as increase of migration of co-cultured PDAC in comparison with monocultured PDAC cells (Kikuta et al. 2010). PDAC cells co-cultivated with activated PSCs seem to have decreased apoptotic response to gemcitabine treatment (Liu et al. 2018).

Epitelial-mesenchymal transformation (EMT), a process of cellular changes resulting in transition of polarised epithelial cells to mesenchymal-like cellular phenotype characterized by increased proliferative and migration potential as well as invasiveness and increased resistance to apoptosis (Kalluri et al. 2010) is an important process in development of PDAC and is also influenced by activated PSCs.

Enhanced changes of PDAC cells typical for EMT transition were described in an in-vitro study where they were co-cultivated with PSCs. Interestingly, these changes were markedly more evident in the presence of high glucose environment (Karnevi et al. 2016) which emphasises the role of type-two diabetes as risk factor of PDAC development. Wu et al. (2017) reported promoting EMT of PDAC cells by IL-6 secreted by PSCs and involving Stat3/Nrf2 pathway. Production of IL-6 by PSCs is also induced by interaction with distinct immune cells. Gamma-delta T-cells promote secretion of IL-6 by PSCs. IL-6 levels correlate with tumor size and moreover has a role in PanIN -> PDAC transition (Seifert et al. 2020). Another cytokine- IL-13 - produced by mastocytes increases proliferation of PSCs (Ma et al. 2013). 
ECM produced by PSCs is essential for PDAC cells survival and metabolism. For example, collagen produced by activated PSCs as the main component of ECM, serves as nutrient reservoir for cancer cells (Olivares et al. 2017) which is important even more as collagen seems to have suppressive effect on neovascularization in PDAC stroma (Berchtold et al. 2014). PSCs play a role in PDAC metabolism also by regulating branched- chain amino acid metabolism (Jiang et al. 2021).

Hypoxia usually accompanying hypovascular PDAC stroma activates PSCs, which produce metalloproteinases. Among these, MMP-10 and MMP-3 seem to promote invasive growth of PDAC (Liu et al. 2020). Under hypoxic condition PSCs secrete connective tissue growth factor (CTGF) which enhances PDAC cells invasion. (Eguchi et al. 2013) Excessive production of ECM further promotes hypoxic microenvironment which is followed by further activation of PSCs. Hypoxic condition leads to expression PSCs derived exosomal miRNA (miR-4465 and miR-616-3p), which promotes PDAC cells proliferation by influencing the PTEN/AKT pathway (Cao et al. 2021).

Moreover, some product released by activated PSCs - e.g. periostin-increase resistance of PDAC cells to hypoxia (Liu et al. 2015). The overall effect of periostin on PDAC invasiveness is probably multiple and perhaps concentration-dependent (Kanno et al. 2008).

Angiogenesis is essential for tumor nutrition and growth. Cancer cells use several factors, like vascular endothelial growth factor (VEGF), to induce angiogenesis in tumor stroma to obtain adequate supply of oxygen and nutrients (Yancopoulos et al. 2000). It was well described that PSC produce many proangiogenic molecules such as basic fibroblast growth factor, periostin and PDGF. As potential therapeutical target miRNA-199a-3p and miRNA-214-3p were described as these miRNAs regulate formation of capillary tubes induced by activated PSCs. (Kuninty et al. 2016) In vitro study of Patel et al. showed that PSCs enhance via HGF/c-MET pathway formation of neovessels by human microvascular endothelial cells (Patel et al. 2014).

It is probably the excessive production of ECM, which - despite strong proangiogenic potential of some products of PSCs - leads to compression of neovessels and hypoxia. It is also worth to mention the reactive defensive regression of neovessels as part of host response on tumor growth (Yancopoulos et al. 2000).

Interesting crosstalk between PSCs and PDAC was described in vitro by Erkan et al. (2009). Although PSCs are under hypoxic condition producents of endothelial growth stimulating VEGF, they stimulate PDAC cells to produce endostatin, which on the contrary supresses angiogenesis. PSCs are also stimulated by PDAC cells to produce metalloproteinases, which cleave endostatin (produced by PDAC) from its precursor.

Perineural invasion, another vicious feature of PDAC is also influenced by PSCs. Nerve growth factor (NGF) was proven to be involved in PDAC growth, perineural invasion and proliferation of PDAC cells. NGF and its receptor TrkA,B,C were found in PDAC tissues (Miknyoczki et al. 1999).

PI3K/AKT pathway was activated by NGF/TrkA which promoted invasion and proliferation in PDAC cells in co-culture with PSCs (Jiang et al. 2020).

Nan et al. showed that HGF/c-Met is essential for perineural invasion of PDAC - it increased production of NGF and MMP - 9 (cellular marker of EMT) and promoted invasion of PDAC in dorsal root ganglia in in-vitro study (Nan et al. 2019).

Interesting is the role of PSCs and PDAC cellular interaction in modulating pancreatic pain which usually accompanies pancreatic cancer. Sonic hedgehog (sHH) secreted by PDAC cells triggers sHH pathway in PSCs. PSCs in reaction secrete several neurotropic factors which are involved in generating pain in pancreatic tissue (Han et al. 2016).

PSCs are able to co-migrate with PDAC cells to distant organs where they can create microenvironment suitable for further growth and spreading of metastatic process. (Suetsugu et al. 2015) PSCs exhibit the ability to in/extravasate cross the endothelial barrier and stimulate angiogenesis in mouse models (Xu et al. 2010).

PSCs seem to be partially responsible for chemoresistance of PDAC. There exist several mechanisms of protecting PDAC cells from effect of chemotherapeutic agents. Massive production of ECM by activated stellate cells generates hypoxic microenvironment of PDAC further facilitating PDAC growth and resulting in worse outcome of chemotherapy. Besides that, PSCs are able to produce molecules which directly promote chemoresistance of PDAC cells e.g., deoxycytidine - deoxynucleoside produced by PSCs reduce effect of nucleoside analogue gemcitabine (Dalin et al. 2019). PSCs also seems to be unaffected by certain regimens of PDAC targeted therapy (Carbera et al. 2014). PSCs / PDAC crosstalk is briefly summarized in Fig. 3. 


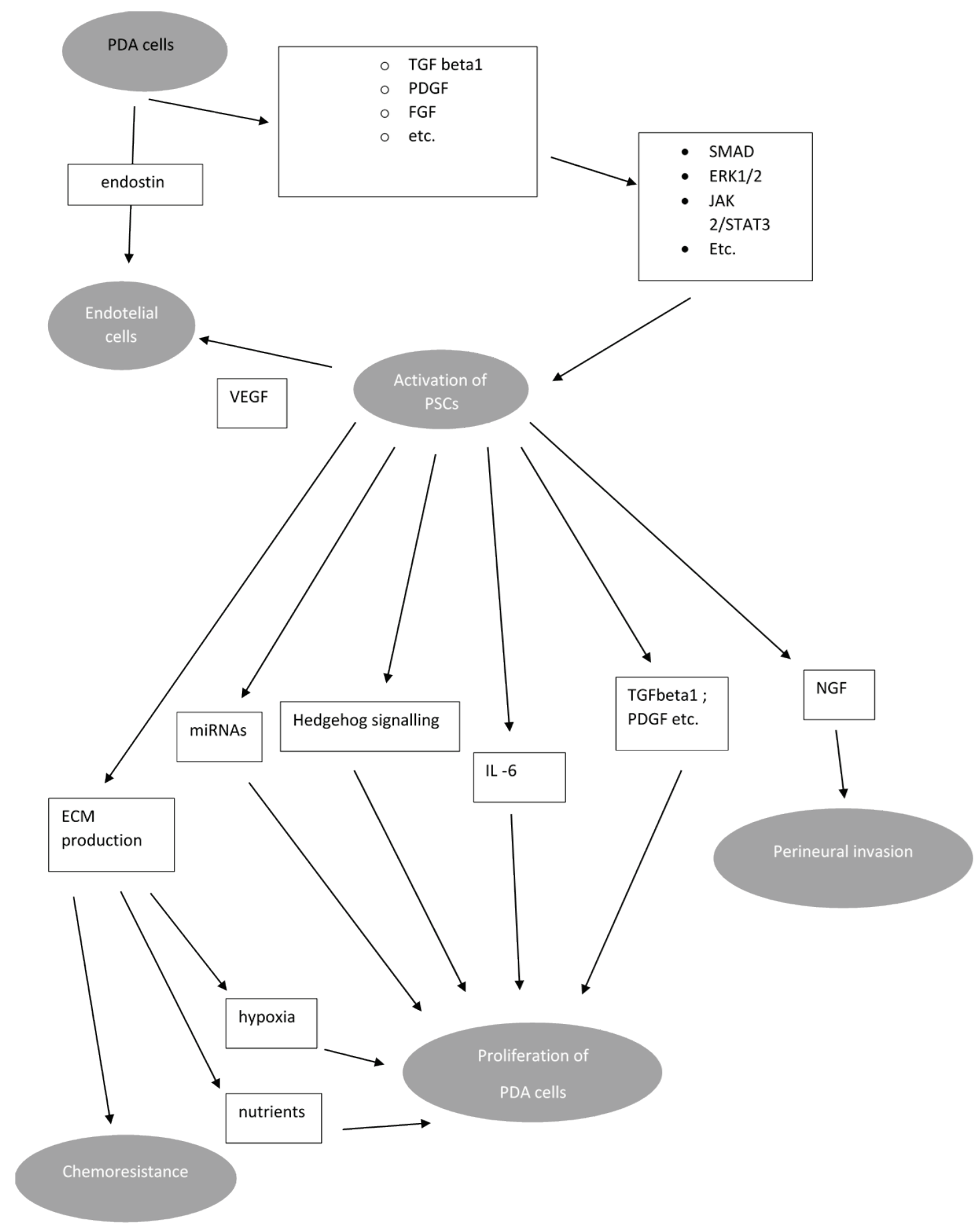

Fig. 3. Crosstalk between malignant cells and PSCs. Factors produced by PSCs increase via several signalling pathways proliferation of malignant cells, perineural invasion, metastasing and chemoresistance. Both PSCs and malignant cells regulates angioneogenesis. Proliferation of malignant cells and hypoxia due to low blood supply increases activation of PSCs. Abbreviations: PDGF : platelet derived growth factor, VEGF - vascular endotelial growth factor, TGF - tumour growth factor; miRNA - microRNA; ECM - extracellular matrix; FGF - fibroblast growth factor; NGF - nerve growth factor; ERK extracellular signal-regulated kinases; JAK- Janus kinase; PDA - pancreatic ductal adenocarcinoma. Modified from: Bynigeri et al. (2017)

\section{PSCs and chronic pancreatitis}

Chronic pancreatitis (CP) is a chronic disease characterised by replacement of functional parenchyma of pancreas by fibrous tissue which in advanced stages results in exocrine and endocrine pancreatic insufficiency. CP is a condition leading to increased risk of pancreatic cancer (Kirkegård et al. 2017). Excessive and persistent activation of PSCs as a result of repeated injury and/or autocrine signalization is the key point of remodelling pancreatic tissue in CP (Jin et al. 2020).

Activation of PSCs is a process accompanying inflammatory reaction in pancreatic tissue and is 
responsible for production of fibrotic stroma typical for PC. There exist several mechanism of PSCs activation in CP. Alcohol - a common cause of CP in western countries- was proved to activate MAPK pathway in PSCs. (McCarroll et al. 2003) Upregulated connective tissue growth factor (CCN2) - exosomal miRNA21 levels forming positive feedback loop responsible for transition of PSCs into myofibroblast-like phenotype was described in mouse models of alcoholic chronic pancreatitis (Charrier et al. 2014).

Smoking was proved as a potential activator of PSCs as PSCs exprime nACH receptors and respond to nicotine-derived nitrosamine ketone - content of cigarette smoke. Cigarette smoke also stimulate T-lymphocytes via aryl-hydrocarbon receptor, which leads to increased levels of IL-22. This cytokine activates PSCs via IL22RA1 (Lee et al. 2015, Xue et al. 2016). The damaged pancreatic acinar cells release various cytokines enhancing activation of PSCs, oxidative stress activates PSCs as well.

In CP, M2 macrophages (unlike in the acute pancreatitis where M1 macrophages dominates (Hu et al. 2020)), play a pivotal role in the pathogenesis of inflammation. The crosstalk between PSCs and macrophages seems to be a crucial mechanism of fibrogenesis in CP. Liu et al revealed in his work - where he studied interaction between co-cultivated PSCs and macrophages - that M2 macrophages produce various cytokines, which have the ability to enhance activation of PSCs e.g., TGF beta 1 and PDGFbeta (Liu et al. 2018). TGF beta 1 also increased procollagen I gene transcription on PSCs and TGF beta signalling in activated PSCs induced a mechanism which inhibits protease-inhibitory function of RECK - membraneanchored MMP inhibitor (Lee et al. 2008).

PSCs are source of IL-4 which in autocrine ways further activates PSCs and macrophages. Besides that, IL-4 works as a potent growth factor for PDAC cells (Prokopchuk et al. 2005). As mentioned previously, activated PSCs produce metalloproteinases and their inhibitors e.g. TIMP-1, TIMP-2, MMP-2, MT1-MMP, which have direct impact on collagen turnover in ECM (Shek et al. 2002).

$\mathrm{NF}-\kappa \mathrm{B}$, depending on the site of production, has impact on the progression of $\mathrm{CP}$ associated fibrosis. NF-KB pathway seems to be activated via TGF beta 1 in PSCs. NF- $\kappa B$ pathway activation in PSCs leads to an imbalance between MMP and TIMPs (in favor of TIMPs) resulting in fibrogenesis. This pathway also increase secretion of MCP -1 with attracts macrophages to the damaged region. This possibly contributes to the vicious circle of persistent fibrogenesis in CP (Prokopchuk et al. 2005).

\section{Conclusion and future directions}

The progress of knowledge about tight relationship between pathologies of pancreas and PSCs and lack of efficient therapy of such debilitating diseases like PDAC and CP necessarily lead to increased interest into PSCs as potent therapeutic target. Commonly used therapy with nab-paclitaxel or FOLFIRINOX does not offer satisfying effectivity. The crosstalk between PDAC and PSCs reveals promising therapeutical targets. In recent years some promising therapeutical strategies were tested, mainly as combination with standard chemotherapy. Targeting pathways involved in PDAC/PSCs crosstalk offer promising strategy of influencing both cancer cells and the stromal component of PDAC mass. The therapy can be focused on reprogramming PSCs to maintain their quiescence, targeting PDAC crosstalk or directly influence production of ECM.

Several studies were focused on influencing different PSCs-associated signalling pathways.

PSCs associated hepatocyte growth factor pathway HGF/c-MET seems to be a promising target of therapy as well as targeting FGF signalling by selective tyrosine-kinase inhibitor (Pothula et al. 2017).

Pancreatic fibrosis, a typical feature of chronic pancreatitis, can be ameliorated by coenzyme Q10, a potent antioxidant, via inhibition PI3K/AKT/mTOR signalling pathway (Xue et al. 2019, Xue et al. 2017).

IL-6 produced in PDAC stroma mainly by PSCs is essential for progression of PDAC (Zhang et al. 2013). Blockade of this cytokine in combination with blockade of programmed death-1-ligand 1 (PD-L1) leads to decreased tumor progression in murine model of pancreatic cancer (Mace et al. 2018). Similar effect was achieved by the use of HSP-90 inhibitor (Zhang et al. 2021).

In in-vitro model, metformin reduces viability and activation of PSCs via angiotensin-II receptor 1 (AT1)/TGF-beta /STAT3 signalling pathway. Furthermore, metformin seems to reduce MMP-9 levels which has beneficial effect on ECM (Incio et al. 2015). Reducing of angiotensin signalling by losartan also reduces the activation of PSCs and combination of losartan with chemotherapy increased survival of mouse 
models of PDAC in comparison with chemotherapy alone (Cauhan et al. 2013). Angiotensin II induced by hyperglycemia increases TGF beta levels, so using reninangiotensin blockers seems to have beneficial effect for patients with DM 2 (Yang et al. 2020).

ATRA is a promising molecule in PDAC involvement as it targets PSCs. It restores mechanical quiescence of PSC via retinoic acid receptor beta (RAR$\beta) /$ actomyosin (MLC-2) pathway. Downregulation of MLC-2 contractility reduces mechanosensing-dependent ECM remodelling which has an effect on cancer cells invasion (Chronopoulos et al. 2016).

It was proved in in-vitro cultures of PSCs by Jaster et al. (2003) that cultures treated by ATRA showed lower proliferation rate and produced less collagen. McCarroll et al. (2005) extended these findings by revealing that cultures of ATRA-treated rat PSCs decreased expression of alpha smooth muscle actin (alpha-SMA) and fibronectin (typical for activated stellate cells) and decreased activation of mitogen activated protein kinase (MAPK) signalling pathways.

Froeling et al. (2011) proved that retinoic acids reduced motility and activation of PSCs and led to increased apoptosis of adjacent cancer cells.

Delivery of ATRA and heat shock protein 47 targeting siRNA by gold-coated nanoparticles which can cross the barrier of ECM induced PSCs quiescence (Han et al. 2018). Combination of gemcitabine and ATRA in in-vitro model shows better effect than gemcitabine alone (Carapuça et al. 2016). Unlike most of other agents, which were tested mainly in-vitro, ATRA as a stromal targeting drug in combination with gemcitabine-nab- paclitaxel was recently tested in phase $\mathrm{Ib}$ of clinical trial performed by Kocher et al. (2020). Antidiabetics can also have effect on PSCs, while suppression of activation of PSCs can be achieved by combination of $\mathrm{N}$-acetyl cysteine and pioglitazone (Feng et al. 2021).

Because of high expression of vit D receptors (VDR) in PSCs, targeting those receptors by VDR ligand calcipotriol leads to reduced inflammation and fibrosis in murine pancreatitis model (Sherman et al. 2014).

These findings show the importance of ECM for proper delivery of chemotherapeutics to PDAC cells. Complex stroma-PDAC interaction highlights the need of sophisticated in vitro models e.g., tumor organoids and 3D models (Norberg et al. 2020). Another goal would be novel strategies of drug delivery to target cells (Huang et al. 2019). In summary, combination therapy targeting both stromal and cancer cells would be optimal strategy to achieve better outcome.

Nevertheless, despite advances in understanding the complex relationship between PSCs and the rest of pancreatic tissue, many studies mentioned were performed on animal models or in-vitro cultures. Thus, further research aimed on in-vivo studies in human pancreas is urgently needed.

\section{Conflict of Interest}

There is no conflict of interest.

\section{Acknowledgements}

This work was supported by DRO GUH64165, Progres Q25 and SVV 260524-2021.

\section{References}

AOKI H, OHNISHI H, HAMA K, SHINOZAKI S, KITA H, YAMAMOTO H, OSAWA H, SATO K, TAMADA K, SUGANO K: Existence of autocrine loop between interleukin-6 and transforming growth factor-beta1 in activated rat pancreatic stellate cells. J Cell Biochem 99: 221-228, 2006. https://doi.org/10.1002/jcb.20906

APTE MV, HABER PS, APPLEGATE TL, NORTON ID, MCCAUGHAN GW, KORSTEN MA, PIROLA RC, WILSON JS: Periacinar stellate shaped cells in rat pancreas: identification, isolation, and culture. Gut. 43: 128-133, 1998. https://doi.org/10.1136/gut.43.1.128

APTE MV, PHILliPS PA, FAHMY RG, DARBY SJ, RODGERS SC, MCCAUGHAN GW, KORSTEN MA, PIROLA RC, NAIDOO D, WILSON JS: Does alcohol directly stimulate pancreatic fibrogenesis? Studies with rat pancreatic stellate cells. Gastroenterology 118: 780-794, 2000. https://doi.org/10.1016/s00165085(00)70148-X

APTE MV, WILSON JS: Stellate cell activation in alcoholic pancreatitis. Pancreas 27: 316-320, 2003. https://doi.org/10.1097/00006676-200311000-00008

ASAHINA K, TSAI SY, LI P, ISHII M, MAXSON RE JR, SUCOV HM, TSUKAMOTO H: Mesenchymal origin of hepatic stellate cells, submesothelial cells, and perivascular mesenchymal cells during mouse liver development. Hepatology 49: 998-1011, 2009. https://doi.org/10.1002/hep.22721 
ASAUMI H, WATANABE S, TAGUCHI M, TASHIRO M, OTSUKI M: Externally applied pressure activates pancreatic stellate cells through the generation of intracellular reactive oxygen species. Am J Physiol Gastrointest Liver Physiol 293: G972-978, 2007. https://doi.org/10.1152/ajpgi.00018.2007

BALMER JE, BLOMHOFF R: Gene expression regulation by retinoic acid. J Lipid Res 43: 1773-1808, 2002. https://doi.org/10.1194/jlr.r100015-jlr200

BERCHTOLD S, GRÜNWALD B, KRÜGER A, REITHMEIER A, HÄHL T, CHENG T, FEUCHTINGER A, BORN D, ERKAN M, KLEEFF J, ESPOSITO I: Collagen type V promotes the malignant phenotype of pancreatic ductal adenocarcinoma. Cancer Lett 28: 721-732, 2015. https://doi.org/10.1016/j.canlet.2014.10.020

BERRY DC, NOY N: All-trans-retinoic acid represses obesity and insulin resistance by activating both peroxisome proliferation-activated receptor beta/delta and retinoic acid receptor. Mol Cell Biol 29: 3286-96, 2009. https://doi.org/10.1128/MCB.01742-08

BLANER WS, O'BYRNE SM, WONGSIRIROJ N, KLUWE J, D'AMBROSIO DM, JIANG H, SCHWABE RF, HILLMAN EM, PIANTEDOSI R, LIBIEN J: Hepatic stellate cell lipid droplets: a specialized lipid droplet for retinoid storage. Biochim Biophys Acta 1791: 467-473, 2009. https://doi.org/10.1016/j.bbalip.2008.11.001

BLEUL T, RÜHL R, BULASHEVSKA S, KARAKHANOVA S, WERNER J, BAZHIN AV: Reduced retinoids and retinoid receptors' expression in pancreatic cancer: A link to patient survival. Mol Carcinog 54: 870-879, 2015. https://doi.org/10.1002/mc.22158.

BYNIGERI RR, JAKKAMPUDI A, JANGALA R, SUBRAMANYAM C, SASIKALA M, RAO GV, REDDY DN, TALUKDAR R: Pancreatic stellate cell: Pandora's box for pancreatic disease biology. World J Gastroenterol 21;23: 382-405, 2017. https://doi.org/10.3748/wjg.v23.i3.382

CABRERA MC, TILAHUN E, NAKLES R, DIAZ-CRUZ ES, CHARABATY A, SUY S, JACKSON P, LEY L, SLACK R, JHA R, COLLINS SP, HADDAD N, KALLAKURY BV, SCHROEDER T, PISHVAIAN MJ, FURTH PA: Human Pancreatic Cancer-Associated Stellate Cells Remain Activated after in vivo Chemoradiation. Front Oncol May 9;4: 102, 2014. https://doi.org/10.3389/fonc.2014.00102

CAO W, ZENG Z, HE Z, LEI S: Hypoxic pancreatic stellate cell-derived exosomal mirnas promote proliferation and invasion of pancreatic cancer through the PTEN/AKT pathway. Aging (Albany NY) 13: 7120-7132, 2021. https://doi.org/10.18632/aging.202569

CARAPUÇA EF, GEMENETZIDIS E, FEIG C, BAPIRO TE, WILLIAMS MD, WILSON AS, DELVECCHIO FR, ARUMUGAM P, GROSE RP, LEMOINE NR, RICHARDS FM, KOCHER HM: Anti-stromal treatment together with chemotherapy targets multiple signalling pathways in pancreatic adenocarcinoma. J Pathol 239: 286-296, 2016. https://doi.org/10.1002/path.4727

CARTER EP, COETZEE AS, TOMAS BORT E, WANG Q, KOCHER HM, GROSE RP. Dissecting FGF signalling to target cellular crosstalk in pancreatic cancer. Cells 10: 847, 2021. https://doi.org/10.3390/cells10040847

CAVE DD, DI GUIDA M, COSTA V, SEVILLANO M, FERRANTE L, HEESCHEN C, CORONA M, CUCCIARDI A, LONARDO E: TGF- $\beta 1$ secreted by pancreatic stellate cells promotes stemness and tumorigenicity in pancreatic cancer cells through L1CAM downregulation. Oncogene 39: 4271-4285, 2020. https://doi.org/10.1038/s41388-020-1289-1

CHARRIER A, CHEN R, CHEN L, KEMPER S, HATTORI T, TAKIGAWA M, BRIGSTOCK DR: Connective tissue growth factor (CCN2) and microRNA-21 are components of a positive feedback loop in pancreatic stellate cells (PSC) during chronic pancreatitis and are exported in PSC-derived exosomes. J Cell Commun Signal 8: 147-156, 2014. https://doi.org/10.1007/s12079-014-0220-3

CHAUHAN VP, MARTIN JD, LIU H, LACORRE DA, JAIN SR, KOZIN SV, STYLIANOPOULOS T, MOUSA AS, HAN X, ADSTAMONGKONKUL P, POPOVIĆ Z, HUANG P, BAWENDI MG, BOUCHER Y, JAIN RK: Angiotensin inhibition enhances drug delivery and potentiates chemotherapy by decompressing tumor blood vessels. Nat Commun 4: 2516, 2013. https://doi.org/10.1038/ncomms3516

CHHATRIYA B, MUKHERJEE M, RAY S, SARKAR P, CHATTERJEE S, NATH D, DAS K, GOSWAMI S: Comparison of tumor and serum specific microRNA changes dissecting their role in pancreatic ductal adenocarcinoma: a meta-analysis. BMC Cancer 19: 1175, 2019. https://doi.org/10.1186/s12885-019-6380-z 
CHRONOPOULOS A, ROBINSON B, SARPER M, CORTES E, AUERNHEIMER V, LACHOWSKI D, ATTWOOD S, GARCÍA R, GHASSEMI S, FABRY B, DEL RÍO HERNÁNDEZ A: ATRA mechanically reprograms pancreatic stellate cells to suppress matrix remodelling and inhibit cancer cell invasion. Nat Commun. 7 : 12630, 2016. https://doi.org/10.1038/ncomms12630

COLVIN EK, SUSANTO JM, KENCH JG, ONG VN, MAWSON A, PINESE M, CHANG DK, ROOMAN I, O'TOOLE SA, SEGARA D, MUSGROVE EA, SUTHERLAND RL, APTE MV, SCARLETT CJ, BIANKIN AV: Retinoid signaling in pancreatic cancer, injury and regeneration. PLoS One 6: e29075, 2011. https://doi.org/10.1371/journal.pone.0029075

DALIN S, SULLIVAN MR, LAU AN, GRAUMAN-BOSS B, MUELLER HS, KREIDL E, FENOGLIO S, LUENGO A, LEES JA, VANDER HEIDEN MG, LAUFFENBURGER DA, HEMANN MT: Deoxycytidine release from pancreatic stellate cells promotes gemcitabine resistance. Cancer Res 79: 5723-5733, 2019. https://doi.org/10.1158/0008-5472.CAN-19-0960

DE SOUZA A, IRFAN K, MASUD F, SAIF MW. Diabetes Type 2 and pancreatic cancer: a history unfolding. JOP 17: 144-148, 2016.

DING Z, MAUBACH G, MASAMUNE A, ZHUO L: Glial fibrillary acidic protein promoter targets pancreatic stellate cells. Dig Liver Dis 41: 229-236, 2009. https://doi.org/10.1016/j.dld.2008.05.001

EBERT M, KASPER HU, HERNBERG S, FRIESS H, BÜCHLER MW, ROESSNER A, KORC M, MALFERTHEINER P: Overexpression of platelet-derived growth factor (PDGF) B chain and type beta PDGF receptor in human chronic pancreatitis. Dig Dis Sci 43: 567-574, 1998. https://doi.org/10.1023/a:1018867209170

EGUCHI D, IKENAGA N, OHUCHIDA K, KOZONO S, CUI L, FUJIWARA K, FUJINO M, OHTSUKA T, MIZUMOTO K, TANAKA M: Hypoxia enhances the interaction between pancreatic stellate cells and cancer cells via increased secretion of connective tissue growth factor. J Surg Res 181: 225-233, 2013. https://doi.org/10.1016/j.jss.2012.06.051

EL-HARIRY I, PIGNATELLI M, LEMOINE NR: FGF-1 and FGF-2 modulate the E-cadherin/catenin system in

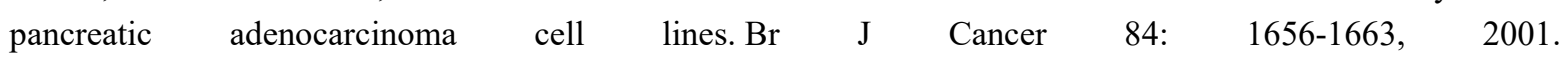
https://doi.org/10.1054/bjoc.2001.1813

ERKAN M, REISER-ERKAN C, MICHALSKI CW, DEUCKER S, SAULIUNAITE D, STREIT S, ESPOSITO I, FRIESS H, KLEEFF J: Cancer-stellate cell interactions perpetuate the hypoxia-fibrosis cycle in pancreatic ductal adenocarcinoma. Neoplasia 11: 497-508, 2009. https://doi.org/10.1593/neo.81618

ESTARAS M, MARTINEZ-MORCILLO S, GARCÍA A, MARTINEZ R, ESTEVEZ M, PEREZ-LOPEZ M, MIGUEZ MP, FERNANDEZ-BERMEJO M, MATEOS JM, VARA D, BLANCO G, LOPEZ D, RONCERO V, SALIDO GM, GONZALEZ A: Pancreatic stellate cells exhibit adaptation to oxidative stress evoked by hypoxia. Biol Cell 112: 280-299, 2020. https://doi.org/10.1111/boc.202000020

FARRAN B, NAGARAJU GP: The dynamic interactions between the stroma, pancreatic stellate cells and pancreatic tumor development: Novel therapeutic targets. Cytokine Growth Factor Rev 48: 11-23, 2019. https://doi.org/10.1016/j.cytogfr.2019.07.001

FENG H, MORIYAMA T, OHUCHIDA K, SHENG N, IWAMOTO C, SHINDO K, SHIRAHANE K, IKENAGA N, NAGAI S, NAKATA K, MIZUMOTO K, NAKAMURA M: N-acetyl cysteine induces quiescent-like pancreatic stellate cells from an active state and attenuates cancer-stroma interactions. J Exp Clin Cancer Res 40: 133, 2021. https://doi.org/10.1186/s13046-021-01939-1

FITZNER B, SPARMANN G, EMMRICH J, LIEBE S, JASTER R: Involvement of AP-1 proteins in pancreatic stellate cell activation in vitro. Int J Colorectal Dis 19: 414-420, 2004. https://doi.org/10.1007/s00384-003-0565

FROELING FE, FEIG C, CHELALA C, DOBSON R, MEIN CE, TUVESON DA, CLEVERS H, HART IR, KOCHER HM: Retinoic acid-induced pancreatic stellate cell quiescence reduces paracrine Wnt- $\beta$-catenin signaling to slow tumor progression. Gastroenterology 141: 1486-1497, 1497.e1-14, 2011. https://doi.org/10.1053/j.gastro.2011.06.047

GAO Z, WANG X, WU K, ZHAO Y, HU G: Pancreatic stellate cells increase the invasion of human pancreatic cancer cells through the stromal cell-derived factor-1/CXCR4 axis. Pancreatology 10: 186-193, 2010. https://doi.org/10.1159/000236012 
GRESS T, MÜLLER-PILLASCH F, ELSÄSSER HP, BACHEM M, FERRARA C, WEIDENBACH H, LERCH M, ADLER G: Enhancement of transforming growth factor beta 1 expression in the rat pancreas during regeneration from caerulein-induced pancreatitis. Eur J Clin Invest 24: 679-685, 1994. https://doi.org/10.1111/j.1365-2362.1994.tb01060

GRYSHCHENKO O, GERASIMENKO JV, GERASIMENKO OV, PETERSEN OH: Calcium signalling in pancreatic stellate cells: Mechanisms and potential roles. Cell Calcium 59: 140-144, 2016. https://doi.org/10.1016/j.ceca.2016.02.003

HAN L, MA J, DUAN W, ZHANG L, YU S, XU Q, LEI J, LI X, WANG Z, WU Z, HUANG JH, WU E, MA Q, MA Z: Pancreatic stellate cells contribute pancreatic cancer pain via activation of sHH signaling pathway. Oncotarget 5: 18146-18158, 2016. https://doi.org/10.18632/oncotarget.7776

HAN X, LI Y, XU Y, ZHAO X, ZHANG Y, YANG X, WANG Y, ZHAO R, ANDERSON GJ, ZHAO Y, NIE: Reversal of pancreatic desmoplasia by re-educating stellate cells with a tumor microenvironment-activated nanosystem. Nat Commun 23: 3390, 2018. https://doi.org/10.1038/s41467-018-05906-X

HONG OK, LEE SH, RHEE M, KO SH, CHO JH, CHOI YH, SONG KH, SON HY, YOON KH: Hyperglycemia and hyperinsulinemia have additive effects on activation and proliferation of pancreatic stellate cells: possible explanation of islet-specific fibrosis in type 2 diabetes mellitus. J Cell Biochem 1;101: 665-675, 2007. https://doi.org/10.1002/jcb.21222

HU C, YANG J, SU HY, WALDRON RT, ZHI M, LI L, XIA Q, PANDOL SJ, LUGEA A: Yes-associated protein 1 plays major roles in pancreatic stellate cell activation and fibroinflammatory responses. Front PhysiolDec 3: 1467, 2019. https://doi.org/10.3389/fphys.2019.01467

HU F, LOU N, JIAO J, GUO F, XIANG H, SHANG D: Macrophages in pancreatitis: Mechanisms and therapeutic potential. Biomed Pharmacother 131: 110693, 2020. https://doi.org/10.1016/j.biopha.2020.110693

HUANG H, BREKKEN RA: The Next Wave of Stroma-Targeting Therapy in Pancreatic Cancer. Cancer Res 15: 328330, 2019. https://doi.org/10.1158/0008-5472.CAN-18-3751

IDE T, KITAJIMA Y, MIYOSHI A, OHTSUKA T, MITSUNO M, OHTAKA K, KOGA Y, MIYAZAKI K: Tumorstromal cell interaction under hypoxia increases the invasiveness of pancreatic cancer cells through the hepatocyte growth factor/c-Met pathway. Int J Cancer 15: 2750-2759, 2006. https://doi.org/10.1002/ijc.22178

INCIO J, SUBOJ P, CHIN SM, VARDAM-KAUR T, LIU H, HATO T, BABYKUTTY S, CHEN I, DESHPANDE V, JAIN RK, FUKUMURA D: Metformin reduces desmoplasia in pancreatic cancer by reprogramming stellate cells and tumor-associated macrophages. PLoS One 7: e0141392, 2015. https://doi.org/10.1371/journal.pone.0141392

INO K, MASUYA M, TAWARA I, MIYATA E, ODA K, NAKAMORI Y, SUZUKI K, OHISHI K, KATAYAMA N: Monocytes infiltrate the pancreas via the MCP-1/CCR2 pathway and differentiate into stellate cells. PLoS One 8: e84889, 2014. https://doi.org/10.1371/journal.pone.0084889

JAKUBOWSKA MA, FERDEK PE, GERASIMENKO OV, GERASIMENKO JV, PETERSEN OH: Nitric oxide signals are interlinked with calcium signals in normal pancreatic stellate cells upon oxidative stress and inflammation. Open Biol 6: 160149, 2016. https://doi.org/10.1098/rsob.160149

JASTER R, HILGENDORF I, FITZNER B, BROCK P, SPARMANN G, EMMRICH J, LIEBE S: Regulation of pancreatic stellate cell function in vitro: biological and molecular effects of all-trans retinoic acid. Biochem Pharmacol 15;66: 633-41, 2003. https://doi.org/10.1016/s0006-2952(03)00390-3

JI T, FENG W, ZHANG X, ZANG K, ZHU X, SHANG F: HDAC inhibitors promote pancreatic stellate cell apoptosis and relieve pancreatic fibrosis by upregulating miR-15/16 in chronic pancreatitis. Hum Cell 33: 1006-1016, 2020. https://doi.org/10.1007/s13577-020-00387-x

JIANG J, BAI J, QIN T, WANG Z, HAN L. NGF from pancreatic stellate cells induces pancreatic cancer proliferation and invasion by PI3K/AKT/GSK signal pathway. J Cell Mol Med 24: 5901-5910, 2020. https://doi.org/10.1111/jcmm.15265

JIANG W, QIAO L, HAN Y, ZHANG A, AN H, XIAO J, REN L.: Pancreatic stellate cells regulate branched-chain amino acid metabolism in pancreatic cancer. Ann Transl Med 9: 417, 2021. https://doi.org/10.21037/atm-21$\underline{761}$ 
JIN G, HONG W, GUO Y, BAI Y, CHEN B: Molecular Mechanism of Pancreatic Stellate Cells Activation in Chronic Pancreatitis and Pancreatic Cancer. J Cancer 14: 1505-1515, 2020. https://doi.org/10.7150/jca.38616

KALLURI R, WEINBERG RA: The basics of epithelial-mesenchymal transition [published correction appears in J Clin Invest. 2010 May 3;120(5):1786]. J Clin Invest 119: 1420-1428, 2009. https://doi.org/10.1172/JCI39104

KANG X, LIN Z, XU M, PAN J, WANG ZW: Deciphering role of FGFR signalling pathway in pancreatic cancer. Cell Prolif 52: e12605, 2019. https://doi.org/10.1111/cpr.12605

KANNO A, SATOH K, MASAMUNE A, HIROTA M, KIMURA K, UMINO J, HAMADA S, SATOH A, EGAWA S, MOTOI F, UNNO M, SHIMOSEGAWA T: Periostin, secreted from stromal cells, has biphasic effect on cell migration and correlates with the epithelial to mesenchymal transition of human pancreatic cancer cells. Int $\mathrm{J}$ Cancer 122: 2707-2718, 2008. https://doi.org/10.1002/ijc.23332

KARNEVI E, ROSENDAHL AH, HILMERSSON KS, SALEEM MA, ANDERSSON R: Impact by pancreatic stellate cells on epithelial-mesenchymal transition and pancreatic cancer cell invasion: Adding a third dimension in vitro. Exp Cell Res 346: 206-15, 2016. https://doi.org/10.1016/j.yexcr.2016.07.017

KIKUTA K, MASAMUNE A, WATANABE T, ARIGA H, ITOH H, HAMADA S, SATOH K, EGAWA S, UNNO M, SHIMOSEGAWA T: Pancreatic stellate cells promote epithelial-mesenchymal transition in pancreatic cancer cells. Biochem Biophys Res Commun 403: 380-384, 2010. https://doi.org/10.1016/j.bbrc.2010.11.040

KIM JJ, LEE E, RYU GR, KO SH, AHN YB, SONG KH: Hypoxia Increases $\beta$-Cell Death by Activating Pancreatic Stellate Cells within the Islet. Diabetes Metab J 44: 919-927, 2020. https://doi.org/10.4093/dmj.2019.0181

KIM JW, KO SH, CHO JH, SUN C, HONG OK, LEE SH, KIM JH, LEE KW, KWON HS, LEE JM, SONG KH, SON HY, YOON KH: Loss of beta-cells with fibrotic islet destruction in type 2 diabetes mellitus. Front Biosci 13: 6022-6033, 2008. https://doi.org/10.2741/3133

KIRKEGÅRD J, MORTENSEN FV, CRONIN-FENTON D. Chronic Pancreatitis and Pancreatic Cancer Risk: A Systematic Review and Meta-analysis. Am J Gastroenterol 112: 1366-1372, 2017. https://doi.org/10.1038/ajg.2017.218

KISS K, BAGHY K, SPISÁK S, SZANYI S, TULASSAY Z, ZALATNAI A, LÖHR JM, JESENOFSKY R, KOVALSZKY I, FIRNEISZ G: Chronic hyperglycemia induces trans-differentiation of human pancreatic stellate cells and enhances the malignant molecular communication with human pancreatic cancer cells. PLoS One 10: e0128059, 2015. https://doi.org/10.1371/journal.pone.0128059

KO SH, HONG OK, KIM JW, AHN YB, SONG KH, CHA BY, SON HY, KIM MJ, JEONG IK, YOON KH: High glucose increases extracellular matrix production in pancreatic stellate cells by activating the renin-angiotensin system. J Cell Biochem 98: 343-355, 2006. https://doi.org/10.1002/jcb.20797

KOCHER HM, BASU B, FROELING FEM, SARKER D, SLATER S, CARLIN D, DESOUZA NM, DE PAEPE KN, GOULART MR, HUGHES C, IMRALI A, ROBERTS R, PAWULA M, HOUGHTON R, LAWRENCE C, YOGESWARAN Y, MOUSA K, COETZEE C, SASIENI P, PRENDERGAST A, PROPPER DJ: Phase I clinical trial repurposing all-trans retinoic acid as a stromal targeting agent for pancreatic cancer. Nat Commun 11: 4841, 2020. https://doi.org/10.1038/s41467-020-18636-w

KUNINTY PR, BOJMAR L, TJOMSLAND V, LARSSON M, STORM G, ÖSTMAN A, SANDSTRÖM P, PRAKASH J: MicroRNA-199a and -214 as potential therapeutic targets in pancreatic stellate cells in pancreatic tumor. Oncotarget 7: 16396-16408, 2016. https://doi.org/10.18632/oncotarget.7651

LEE AT, XU Z, POTHULA SP, PATEL MB, PIROLA RC, WILSON JS, APTE MV: Alcohol and cigarette smoke components activate human pancreatic stellate cells: implications for the progression of chronic pancreatitis. Alcohol Clin Exp Res 39: 2123-2133, 2015. https://doi.org/10.1111/acer.12882

LEE H, LIM C, LEE J, KIM N, BANG S, LEE H, MIN B, PARK G, NODA M, STETLER-STEVENSON WG, OH J: TGF-beta signaling preserves RECK expression in activated pancreatic stellate cells. J Cell Biochem 104: 1065-1074, 2008. https://doi.org/10.1002/jcb.21692

LI Z, ZHANG X, JIN T, HAO J: Nicotine promotes activation of human pancreatic stellate cells through inducing autophagy via $\alpha 7 n A C h R-m e d i a t e d ~ J A K 2 / S T A T 3$ signaling pathway. Life Sci 243: 117301, 2020. https://doi.org/10.1016/j.lfs.2020.117301 
LIN H, DONG B, QI L, WEI Y, ZHANG Y, CAI X, ZHANG Q, LI J, LI L: Inhibitory Smads suppress pancreatic stellate cell activation through negative feedback in chronic pancreatitis. Ann Transl 9: 384, 2021. https://doi.org/10.21037/atm-20-4282

LIU D, STEINS A, KLAASSEN R, VAN DER ZALM AP, BENNINK RJ, VAN TIENHOVEN G, BESSELINK MG, BIJLSMA MF, VAN LAARHOVEN HWM: Soluble compounds released by hypoxic stroma confer invasive properties to pancreatic ductal adenocarcinoma. Biomedicines 8: $444,2020$. https://doi.org/10.3390/biomedicines811044

LIU SL, CAO SG, LI Y, SUN B, CHEN D, WANG DS, ZHOU YB: Pancreatic stellate cells facilitate pancreatic cancer cell viability and invasion. Oncol Lett 17: 2057-2062, 2019. https://doi.org/10.3892/ol.2018.9816

LIU Y, DU L: Role of pancreatic stellate cells and periostin in pancreatic cancer progression. Tumor Biol 36: 3171-3177, 2015. https://doi.org/10.1007/s13277-015-3386-2

LIU Z, KUANG W, ZHOU Q, ZHANG Y: TGF- $\beta 1$ secreted by M2 phenotype macrophages enhances the stemness and migration of glioma cells via the SMAD2/3 signalling pathway. Int J Mol 42: 3395-3403, 2018. https://doi.org/10.3892/ijmm.2018.3923

LUTTENBERGER T, SCHMID-KOTSAS A, MENKE A, SIECH M, BEGER H, ADLER G, GRÜNERT A, BACHEM MG: Platelet-derived growth factors stimulate proliferation and extracellular matrix synthesis of pancreatic stellate cells: implications in pathogenesis of pancreas fibrosis. Lab Invest 80: 47-55, 2000. https://doi.org/10.1038/labinvest.3780007

MA Q, WU H, XIAO Y, LIANG Z, LIU T: Upregulation of exosomal microRNA-21 in pancreatic stellate cells promotes pancreatic cancer cell migration and enhances Ras/ERK pathway activity. Int J Oncol 56: 1025-1033, 2020. https://doi.org/10.3892/ijo.2020.4986

MA Y, HWANG RF, LOGSDON CD, ULLRICH SE: Dynamic mast cell-stromal cell interactions promote growth of pancreatic cancer. Cancer Res 73: 3927-3937, 2013. https://doi.org/10.1158/0008-5472.CAN-12-4479

MACE TA, SHAKYA R, PITARRESI JR, SWANSON B, MCQUINN CW, LOFTUS S, NORDQUIST E, CRUZ-MONSERRATE Z, YU L, YOUNG G, ZHONG X, ZIMMERS TA, OSTROWSKI MC, LUDWIG T, BLOOMSTON M, BEKAII-SAAB T, LESINSKI GB: IL-6 and PD-L1 antibody blockade combination therapy reduces tumor progression in murine models of pancreatic cancer. Gut Feb 67: 320-332, 2018. https://doi.org/10.1136/gutjnl-2016-311585

MASAMUNE A, NAKANO E, HAMADA S, TAKIKAWA T, YOSHIDA N, SHIMOSEGAWA T: Alteration of the microRNA expression profile during the activation of pancreatic stellate cells. Scand J Gastroenterol 49: 323-331, 2014. https://doi.org/10.3109/00365521.2013.876447

MASAMUNE A, SAKAI Y, KIKUTA K, SATOH M, SATOH A, SHIMOSEGAWA T: Activated rat pancreatic stellate cells express intercellular adhesion molecule-1 (ICAM-1) in vitro. Pancreas 25: 78-85, 2002. https://doi.org/10.1097/00006676-200207000-00018

MASAMUNE A, YOSHIDA N, HAMADA S, TAKIKAWA T, NABESHIMA T, SHIMOSEGAWA T. Exosomes derived from pancreatic cancer cells induce activation and profibrogenic activities in pancreatic stellate cells. Biochem Biophys Res Commun 495: 71-77, 2018. https://doi.org/10.1016/j.bbrc.2017.10.141

MCCARROLL JA, PHILLIPS PA, PARK S, DOHERTY E, PIROLA RC, WILSON JS, APTE MV: Pancreatic stellate cell activation by ethanol and acetaldehyde: is it mediated by the mitogen-activated protein kinase signaling pathway? Pancreas 27: 150-160, 2003. https://doi.org/10.1097/00006676-200308000-00008

MCCARROLL JA, PHILLIPS PA, SANTUCCI N, PIROLA RC, WILSON JS, APTE MV: Vitamin A inhibits pancreatic stellate cell activation: implications for treatment of pancreatic fibrosis. Gut 55: 79-89, 2006. https://doi.org/10.1136/gut.2005.064543

MIKNYOCZKI SJ, LANG D, HUANG L, KLEIN-SZANTO AJ, DIONNE CA, RUGGERI BA: Neurotrophins and Trk receptors in human pancreatic ductal adenocarcinoma: expression patterns and effects on in vitro invasive behavior. Int J Cancer 81: 417-427, 1999. https://doi.org/10.1002/(sici)1097-0215(19990505)81:3<417::aidijc16>3.0.co;2-6

MORRISON CD, PARVANI JG, SCHIEMANN WP: The relevance of the TGF- $\beta$ Paradox to EMT-MET programs. Cancer Lett Nov 341: 30-40, 2013. https://doi.org/10.1016/j.canlet.2013.02.048 
NAN L, QIN T, XIAO Y, QIAN W, LI J, WANG Z, MA J, MA Q, WU Z: Pancreatic Stellate Cells Facilitate Perineural Invasion of Pancreatic Cancer via HGF/c-Met Pathway. Cell Transplant 28: 1289-1298, 2019. https://doi.org/10.1177/0963689719851772

NORBERG KJ, LIU X, FERNÁNDEZ MORO C, STRELL C, NANIA S, BLÜMEL M, BALBONI A, BOZÓKY, HEUCHEL RL, LÖHR JM: A novel pancreatic tumor and stellate cell 3D co-culture spheroid model. BMC Cancer 20: 475, 2020. https://doi.org/10.1186/s12885-020-06867-5

OLIVARES O, MAYERS JR, GOUIRAND V, TORRENCE ME, GICQUEL T, BORGE L, LAC S, ROQUES J, LAVAUT MN, BERTHEZĖNE P, RUBIS M, SECQ V, GARCIA S, MOUTARDIER V, LOMBARDO D, IOVANNA JL, TOMASINI R, GUILLAUMOND F, VANDER HEIDEN MG, VASSEUR S: Collagenderived proline promotes pancreatic ductal adenocarcinoma cell survival under nutrient limited conditions. Nat Commun 8: 16031, 2017. https://doi.org/10.1038/ncomms16031

OMARY MB, COULOMBE PA, MCLEAN WH: Intermediate filament proteins and their associated diseases. N Engl J Med 351: 2087-2100, 2004. https://doi.org/10.1056/NEJMra040319

PANDOL S, GUKOVSKAYA A, EDDERKAOUI M, DAWSON D, EIBL G, LUGEA A: Epidemiology, risk factors, and the promotion of pancreatic cancer: role of the stellate cell [published correction appears in J Gastroenterol Hepatol 27: 990, 2012. https://doi.org/10.1111/j.1440-1746.2011.07013.x

PATEL MB, POTHULA SP, XU Z, LEE AK, GOLDSTEIN D, PIROLA RC, APTE MV, WILSON JS: The role of the hepatocyte growth factor/c-MET pathway in pancreatic stellate cell-endothelial cell interactions: antiangiogenic implications in pancreatic cancer. Carcinogenesis 35: 1891-1900, 2014. https://doi.org/10.1093/carcin/bgu122

PEDERSEN N, LARSEN S, SEIDELIN JB, NIELSEN OH: Alcohol modulates circulating levels of interleukin-6 and monocyte chemoattractant protein-1 in chronic pancreatitis. Scand J Gastroenterol 39: 277-282, 2004. https://doi.org/10.1080/00365520310008296

PETERSEN OH, SUTTON R: Ca2+ signalling and pancreatitis: effects of alcohol, bile and coffee. Trends Pharmacol Sci 27: 113-120, 2006. https://doi.org/10.1016/j.tips.2005.12.006

PHILLIPS PA, MCCARROLL JA, PARK S, WU MJ, PIROLA R, KORSTEN M, WILSON JS, APTE MV: Rat pancreatic stellate cells secrete matrix metalloproteinases: implications for extracellular matrix turnover. Gut 52: 275-282, 2003. https://doi.org/10.1136/gut.52.2.275

POTHULA SP, XU Z, GOLDSTEIN D, MERRETT N, PIROLA RC, WILSON JS, APTE MV: Targeting the HGF/c-MET pathway: stromal remodelling in pancreatic cancer. Oncotarget 8: 76722-76739, 2017. https://doi.org/10.18632/oncotarget.20822

PROKOPCHUK O, LIU Y, HENNE-BRUNS D, KORNMANN M: Interleukin-4 enhances proliferation of human pancreatic cancer cells: evidence for autocrine and paracrine actions. Br J Cancer 92: 921-928, 2005. https://doi.org/10.1038/sj.bjc.6602416

RICHARDS KE, ZELENIAK AE, FISHEL ML, WU J, LITTLEPAGE LE, HILL R: Cancer-associated fibroblast exosomes regulate survival and proliferation of pancreatic cancer cells. Oncogene 36: 1770-1778, 2017. https://doi.org/10.1038/onc.2016.353

ROW S, LIU Y, ALIMPERTI S, AGARWAL SK, ANDREADIS ST: Cadherin-11 is a novel regulator of extracellular matrix synthesis and tissue mechanics. J Cell Sci 129: 2950-2961, 2016. https://doi.org/10.1242/jcs.183772

SARPER M, CORTES E, LIEBERTHAL TJ, DEL RÍO HERNÁNDEZ A: ATRA modulates mechanical activation of TGF- $\beta$ by pancreatic stellate cells. Sci Rep 6:27639, 2016. https://doi.org/10.1038/srep27639

SATO Y, ENDO H, OKUYAMA H, TAKEDA T, IWAHASHI H, IMAGAWA A, YAMAGATA K, SHIMOMURA I, INOUE M: Cellular hypoxia of pancreatic beta-cells due to high levels of oxygen consumption for insulin secretion in vitro. J Biol Chem 286: 12524-12532, 2011. https://doi.org/10.1074/jbc.M110.194738

SEIFERT AM, LIST J, HEIDUK M, ET AL: Gamma-delta T cells stimulate IL-6 production by pancreatic stellate cells in pancreatic ductal adenocarcinoma. J Cancer Res Clin Oncol 146: 3233-3240, 2020. https://doi.org/10.1007/s00432-020-03367-8

SHAO F, CAI M, FAN FF, HUANG M, TAO Y, WANG C, MENG FT, HUANG Q: Overexpression of circRNA chr7:154954255-154998784+ in cancer-associated pancreatic stellate cells promotes the growth and metastasis of pancreatic cancer by targeting the miR-4459/KIAA0513 axis. Am J Transl Res 12: 5048-5063, 2020. 
SHEK FW, BENYON RC, WALKER FM, MCCRUDDEN PR, PENDER SL, WILLIAMS EJ, JOHNSON PA, JOHNSON CD, BATEMAN AC, FINE DR, IREDALE JP: Expression of transforming growth factor-beta 1 by pancreatic stellate cells and its implications for matrix secretion and turnover in chronic pancreatitis. Am J Pathol 160: 1787-1798, 2002. https://doi.org/10.1016/s0002-9440(10)61125-X

SHERMAN MH, YU RT, ENGLE DD, DING N, ATKINS AR, TIRIAC H, COLLISSON EA, CONNOR F, VAN DYKE T, KOZLOV S, MARTIN P, TSENG TW, DAWSON DW, DONAHUE TR, MASAMUNE A, SHIMOSEGAWA T, APTE MV, WILSON JS, NG B, LAU SL, GUNTON JE, WAHL GM, HUNTER T, DREBIN JA, O'DWYER PJ, LIDDLE C, TUVESON DA, DOWNES M, EVANS RM: Vitamin D receptormediated stromal reprogramming suppresses pancreatitis and enhances pancreatic cancer therapy. Cell 159: 8093, 2014. https://doi.org/10.1016/j.cell.2014.08.007

SHIMIZU K, KOBAYASHI M, TAHARA J, SHIRATORI K: Cytokines and peroxisome proliferator-activated receptor gamma ligand regulate phagocytosis by pancreatic stellate cells. Gastroenterology 128: 2105-2118, 2005. https://doi.org/10.1053/j.gastro.2005.03.025

SPARMANN G, KRUSE ML, HOFMEISTER-MIELKE N, KOCZAN D, JASTER R, LIEBE S, WOLFF D, EMMRICH J: BONE marrow-derived pancreatic stellate cells in rats. Cell Res 20: 288-298, 2010. https://doi.org/10.1038/cr.2010.10

STORCK H, HILD B, SCHIMMELPFENNIG S, SARGIN S, NIELSEN N, ZACCAGNINO A, BUDDE T, NOVAK I, KALTHOFF H, SCHWAB A: Ion channels in control of pancreatic stellate cell migration. Oncotarget 8 : 769-784, 2017. https://doi.org/10.18632/oncotarget.13647

STORZ G: An expanding universe of noncoding RNAs. Science 296: 1260-1263, 2002. https://doi.org/10.1126/science.1072249

SUETSUGU A, SNYDER CS, MORIWAKI H, SAJI S, BOUVET M, HOFFMAN RM: Imaging the Interaction of Pancreatic Cancer and Stellate Cells in the Tumor Microenvironment during Metastasis. Anticancer Res 35: 2545-2551, 2015.

SUN L, XIU M, WANG S, BRIGSTOCK DR, LI H, QU L, GAO R: Lipopolysaccharide enhances TGF- $\beta 1$ signalling pathway and rat pancreatic fibrosis. J Cell Mol Med 22: 2346-2356, 2018. https://doi.org/10.1111/jcmm.13526

SUZUKI R, ASAMA H, WARAGAI Y, TAKAGI T, HIKICHI T, SUGIMOTO M, KONNO N, WATANABE K, NAKAMURA J, KIKUCHI H, SATO Y, MARUBASHI S, MASAMUNE A, OHIRA H: Fibrosis-related miRNAs as serum biomarkers for pancreatic ductal adenocarcinoma. Oncotarget 9: 4451-4460, 2017. https://doi.org/10.18632/oncotarget.23377

TULACHAN SS, DOI R, KAWAGUCHI Y, TSUJI S, NAKAJIMA S, MASUI T, KOIZUMI M, TOYODA E, MORI T, ITO D, KAMI K, FUJIMOTO K, IMAMURA M: All-trans retinoic acid induces differentiation of ducts and endocrine cells by mesenchymal/epithelial interactions in embryonic pancreas. Diabetes 52: 76-84, 2003. https://doi.org/10.2337/diabetes.52.1.76

UYAMA N, ZHAO L, VAN ROSSEN E, HIRAKO Y, REYNAERT H, ADAMS DH, XUE Z, LI Z, ROBSON R, PEKNY M, GEERTS A: Hepatic stellate cells express synemin, a protein bridging intermediate filaments to focal adhesions. Gut 55: 1276-1289, 2006. https://doi.org/10.1136/gut.2005.078865

VAN ROSSEN E, LIU Z, BLIJWEERT D, EYSACKERS N, MANNAERTS I, SCHROYEN B, EL TAGHDOUINI A, EDWARDS B, DAVIES KE, SOKAL E, NAJIMI M, REYNAERT H, VAN GRUNSVEN LA: Syncoilin is an intermediate filament protein in activated hepatic stellate cells. Histochem Cell Biol 141: 85-99, 2014. https://doi.org/10.1007/s00418-013-1142-5

VON KUPFFER C: Ueber Sternzellen der Leber. Briefliche Mitteilung an Prof. Waldyer. Arch mikr Anat 12: 353-358, 1876.

VONLAUFEN A, XU Z, DANIEL B, KUMAR RK, PIROLA R, WILSON J, APTE MV: Bacterial endotoxin: a trigger factor for alcoholic pancreatitis? Evidence from a novel, physiologically relevant animal model. Gastroenterology 133: 1293-1303, 2007. https://doi.org/10.1053/j.gastro.2007.06.062

WAKE K. Hepatic Stellate Cells. In: Tanikawa K., Ueno T: (eds) Liver Diseases and Hepatic Sinusoidal Cells. Springer, Tokyo, 1999. https://doi.org/10.1007/978-4-431-67935-6_3 
WANG H, JIANG Y, LU M, SUN B, QIAO X, XUE D, ZHANG W: STX12 lncRNA/miR-148a/SMAD5 participate in the regulation of pancreatic stellate cell activation through a mechanism involving competing endogenous RNA. Pancreatology 17: 237-246, 2017. https://doi.org/10.1016/j.pan.2017.01.010

WANG Q, WANG H, JING Q, YANG Y, XUE D, HAO C, ZHANG W: Regulation of Pancreatic Fibrosis by Acinar Cell-Derived Exosomal miR-130a-3p via Targeting of Stellate Cell PPAR- $\gamma$. J Inflamm Res 14: 461-477, 2021. https://doi.org/10.2147/JIR.S299298

WATARI N, HOTTA Y, MABUCHI Y: Morphological studies on a vitamin A-storing cell and its complex with macrophage observed in mouse pancreatic tissues following excess vitamin A administration. Okajimas Folia Anat Jpn 58: 837-58, 1982. https://doi.org/10.2535/ofaj1936.58.4-6 837

WU N, XU XF, XIN JQ, FAN JW, WEI YY, PENG QX, DUAN LF, WANG W, ZHANG H: The effects of nuclear factor-kappa B in pancreatic stellate cells on inflammation and fibrosis of chronic pancreatitis. J Cell Mol Med 25: 2213-2227, 2021. https://doi.org/10.1111/jcmm.16213

WU Y, ZHANG C, JIANG K, WERNER J, BAZHIN AV, D'HAESE JG: The role of stellate cells in pancreatic ductal adenocarcinoma: targeting perspectives. Front Oncol 10: 621937, 2021. https://doi.org/10.3389/fonc.2020.621937

WU YS, CHUNG I, WONG WF, MASAMUNE A, SIM MS, LOOI CY. Paracrine IL-6 signaling mediates the effects of pancreatic stellate cells on epithelial-mesenchymal transition via Stat3/Nrf2 pathway in pancreatic cancer cells. Biochim Biophys Acta Gen Subj 1861: 296-306, 2017. https://doi.org/10.1016/j.bbagen.2016.10.006

XIN L, GAO J, WANG D, LIN JH, LIAO Z, JI JT, DU TT, JIANG F, HU LH, LI ZS: Novel blood-based microRNA biomarker panel for early diagnosis of chronic pancreatitis. Sci Rep 7: 40019, 2017. https://doi.org/10.1038/srep40019

XU J, LIU S, YANG X, CAO S, ZHOU Y: Paracrine HGF promotes EMT and mediates the effects of PSC on chemoresistance by activating c-Met/PI3K/Akt signaling in pancreatic cancer in vitro. Life Sci 263: 118523, 2020. https://doi.org/10.1016/j.lfs.2020.118523

XU M, WANG G, ZHOU H, CAI J, LI P, ZHOU M, LU Y, JIANG X, HUANG H, ZHANG Y, GONG A: TGF-31-miR-200a-PTEN induces epithelial-mesenchymal transition and fibrosis of pancreatic stellate cells. Mol Cell Biochem 431: 161-168, 2017. https://doi.org/10.1007/s11010-017-2988-y

XU XF, LIU F, XIN JQ, FAN JW, WU N, ZHU LJ, DUAN LF, LI YY, ZHANG H: Respective roles of the mitogenactivated protein kinase (MAPK) family members in pancreatic stellate cell activation induced by transforming growth factor- $\beta 1$ (TGF- $\beta 1)$. Biochem Biophys Res Commun 501: 365-373, 2018. https://doi.org/10.1016/j.bbrc.2018.04.176

XU Z, VONLAUFEN A, PHILLIPS PA, FIALA-BEER E, ZHANG X, YANG L, BIANKIN AV, GOLDSTEIN D, PIROLA RC, WILSON JS, APTE MV: Role of pancreatic stellate cells in pancreatic cancer metastasis. Am J Pathol 177: 2585-2596, 2010. https://doi.org/10.2353/ajpath.2010.090899

XUE J, ZHAO Q, SHARMA V, NGUYEN LP, LEE YN, PHAM KL, EDDERKAOUI M, PANDOL SJ, PARK W, HABTEZION A: Aryl hydrocarbon receptor ligands in cigarette smoke induce production of Interleukin-22 to promote pancreatic fibrosis in models of chronic pancreatitis. Gastroenterology 151: 1206-1217, 2016. https://doi.org/10.1053/j.gastro.2016.09.064

XUE R, WANG J, YANG L, LIU X, GAO Y, PANG Y, WANG Y, HAO J: Coenzyme Q10 Ameliorates Pancreatic Fibrosis via the ROS-Triggered mTOR Signaling Pathway. Oxid Med Cell Longev 2019: 8039694, 2019. https://doi.org/10.1155/2019/8039694

XUE R, YANG J, WU J, MENG Q, HAO J: Coenzyme Q10 inhibits the activation of pancreatic stellate cells through $\begin{array}{llll}\mathrm{PI} 3 \mathrm{~K} / \mathrm{AKT} / \mathrm{mTOR} \quad \text { signaling } & \text { pathway. Oncotarget } & \text { 8: }\end{array}$ https://doi.org/10.18632/oncotarget.21247

YAN Z, OHUCHIDA K, FEI S, ZHENG B, GUAN W, FENG H, KIBE S, ANDO Y, KOIKAWA K, ABE T, IWAMOTO C, SHINDO K, MORIYAMA T, NAKATA K, MIYASAKA Y, OHTSUKA T, MIZUMOTO K, HASHIZUME M, NAKAMURA M: Inhibition of ERK1/2 in cancer-associated pancreatic stellate cells suppresses cancer-stromal interaction and metastasis. J Exp Clin Cancer Res. 38: 221, 2019. https://doi.org/10.1186/s13046-019-1226-8 
YANCOPOULOS GD, DAVIS S, GALE NW, RUDGE JS, WIEGAND SJ, HOLASH J: Vascular-specific growth factors and blood vessel formation. Nature 407: 242-248, 2000. https://doi.org/10.1038/35025215

YANG Y, KIM JW, PARK HS, LEE EY, YOON KH: Pancreatic stellate cells in the islets as a novel target to preserve the pancreatic $\beta$-cell mass and function. J Diabetes Investig 11: 268-280, 2020. https://doi.org/10.1111/jdi.13202

YANG Y, YU X, HUANG L, YU C: GLP-1R agonist may activate pancreatic stellate cells to induce rat pancreatic tissue lesion. Pancreatology 13: 498-501, 2013. https://doi.org/10.1016/j.pan.2013.07.281

ZHA M, LI F, XU W, CHEN B, SUN Z: Isolation and characterization of islet stellate cells in rat. Islets 6: e28701, 2014. https://doi.org/10.4161/isl.28701

ZHANG Y, WARE MB, ZAIDI MY, RUGGIERI AN, OLSON BM, KOMAR H, FARREN MR, NAGARAJU GP, ZHANG C, CHEN Z, SARMIENTO JM, AHMED R, MAITHEL SK, EL-RAYES BF, LESINSKI GB: Heat Shock Protein-90 Inhibition Alters Activation of Pancreatic Stellate Cells and Enhances the Efficacy of PD-1 Blockade in Pancreatic Cancer. Mol Cancer Ther 20: 150-160, 2021. https://doi.org/10.1158/1535-7163.MCT$\underline{19-0911}$

ZHANG Y, YAN W, COLLINS MA, BEDNAR F, RAKSHIT S, ZETTER BR, STANGER BZ, CHUNG I, RHIM AD, DI MAGLIANO MP: Interleukin-6 is required for pancreatic cancer progression by promoting MAPK signaling activation and oxidative stress resistance. Cancer Res 73: 6359-6374, 2013. https://doi.org/10.1158/0008-5472.CAN-13-1558-T

ZHOU W, CHEN L, LI C, HUANG R, GUO M, NING S, JI J, GUO X, LOU G, JIA X, ZHAO J, LUO F, LI C, QU Z, YU S, TAI S: The multifaceted roles of long noncoding RNAs in pancreatic cancer: an update on what we know. Cancer Cell Int 20: 41, 2020. https://doi.org/10.1186/s12935-020-1126-1

ZHOU Y, SUN B, LI W, ZHOU J, GAO F, WANG X, CAI M, SUN Z: Pancreatic stellate cells: a rising translational physiology star as a potential stem cell type for beta cell neogenesis. Front Physiol 10: 218, 2019. https://doi.org/10.3389/fphys.2019.00218

ZHOU Y, WANG H, ZHOU J, QIU S, CAI T, LI H, SHEN Z, HU Y, DING B, LUO M, HUANG R, YAN R, XU W, HE C, ZHANG Y, LI F, SUN Z, MA J: Vitamin A and its multi-effects on pancreas: recent advances and prospects. Front Endocrinol (Lausanne) 12: 620941, 2021. https://doi.org/10.3389/fendo.2021.620941

ZHOU Y, ZHOU J, SUN B, XU W, ZHONG M, LI Y, HE C, CHEN Y, WANG X, JONES PM, SUN Z: Vitamin A deficiency causes islet dysfunction by inducing islet stellate cell activation via cellular retinol binding protein 1. Int J Biol Sci 16: 947-956, 2020. https://doi.org/10.7150/ijbs.37861 